\title{
HAKIKAT KASIH SAYANG, KEWIBAWAAN DAN TANGGUNG JAWAB
}

\author{
${ }^{1}$ Ayu Reskiya, ${ }^{2}$ Nurlina, ${ }^{3}$ Nurul Mawaddah, ${ }^{4}$ Muhammad Yacub \\ Ayureskiya4@gmail.com
}

\section{INSTITUT AGAMA ISLAM MUHAMMADIYAH (IAIM) SINJAI}

\begin{abstract}
ABSTRAK
Pendidik merupakan orang dewasa yang membimbing anak agar si anak tersebut bisa menuju ke arah kedewasaan. Peran orang dewasa di dalam proses pembelajaran sangat penting karena tidak mungkin orangyang belum dewasa mendewasakan orang yang belum dewasa. Sosok pendidik begitu besar dalam proses pembelajaran dalam mendidik, mengajar, membimbing, mengarahan, melatih, menilai, dan mengevaluasi peserta didik, namun selain itu seorang pendidik harus memiliki suatu kasih sayang, kewibawaan dan tanggung jawab terhadap peserta didiknya. Pada prakteknya, ternyata menerapkan kasih sayang, kewibawaan, dan tanggung jawab dalam proses pendidikan tidak mudah, banyak hambatan dan kendala yang dihadapi pendidik, baik berkaitan dengan pemahaman maupun kemampuan pendidik. Untuk itu, kemauan dan ketulusan pendidik dalam menjalankan tugasnya menjadi dasar dalam memahami sifat dan sikap anak didik.

Kasih sayang, kewibawaan, dan tanggung jawab pendidikan, merupakan suatu kesatuan yang tidak dapat dipisahkan karena suatu ruh dari pendidikan atau menjadi suatu yang perlu dimiliki oleh seorang pendidik. Tanpa kasih sayang anak akan berkembang menurut kemauan-kemauannya sendiri, karena pendidik sama sekali tidak peduli terhadap perkembangan peserta didiknya. Tanpa kewibawaan, pendidik akan kehilangan kepercayaan dari peserta didiknya. Peserta didik bertindak semaunya tanpa peduli terhadap pendidiknya. Semua upaya
\end{abstract}


pendidik mungkin akan dilecehkan oleh peserta didiknya. Tanpa tanggung jawab dari pendidik, upaya pendidik tidak akan memiliki arah tujuan, karena pendidik akan acuh dalam melaksanakan tugasnya sebagai orang dewasayang harus membawa anak kepada kedewasaan. Maka dari itu kami dalam malakah ini akan membahas tentang kasih sayang, kewibawaan, dan tanggung jawab pendidikan. 


\section{BAB II}

\section{PEMBAHASAN}

\section{A. Hakikat Kasih Sayang}

Kasih sayang merupakan fitrah manusia, artinya setiap manusia ditakdirkan oleh Allah memiliki kasih sayang terhadap semuanya. Dalam hal pendidikan, kasih sayang harus mendasari semua upaya dalam membawa anak menuju tujuannya, yaitu kedewasaan. Kasih sayang yang berlebihan dan hidup tanpa kasih:

a. Kasih sayang yang Berlebihan

Sebagai orang tua yang baik mereka harus mempersiapkan sesuatu untuk masa depan anak-anak mereka. Anak harus dididik supaya menjadi manusia yang tangguh pada saat ia telah dewasa. Jangan membiarkan mereka menjadi anak yang tidak berdaya, lemah dan selalu mengharapkan uluran tangan orang lain.

Sadulloh (2011, hlm. 159) menyatakan bahwa kasih sayang yang berlebihan dapat menimbulkan dampak negatif diantaranya:

1) Akan tumbuh sikap yang selalu ingin diperlakukan secara istimewa. Sifat-sifat seorang otoriter dalam diri anak semakin berkembang ketika orang tua selalu memenuhi segala keinginanankeinginanya. Benih-benih kediktoratan semakin bersemi di dalam dirinya. Ketika hidup di tengah-tengah masyarakat, ia ingin semua orang memperlakukan dirinya seperti orang tuanya dulu melayano dirinya. Orang seperti itu akan mudah putus asa kalau keinginanya tidak ada yang memperhatikan dan tidak memperoleh simpati dari orang lain.

2) Anak yang selalu di manja dapat mengalami masalah dalam kehidupan rumah tangganya dikemudian hari, mungkin ia akan 
meminta dilayani istrinya secara sempurna mungkin yang lebih tidak baik lagi ia suka memperlakukan istrinya seperti pembantu yang harus tunduk pada perintahnya.

3) Anak yang dibesarkan dalam asuhan kasih sayang berlebihan dapat menjadi anak yang sangat rentan dengan masalah, kehilangan kepercayaan diri, tidak mengambil risiko, tidak mau melakukan pekerjaan-pekerjaan yang penting dan selalau mengharapkn uluran tangan orang lain.

4) Anak tidak mau mengembangkan diri karena merasa cukup dengan apa yang diterimanya. Orang tuanya telah memenuhi segala keinginannya, pujian dan segalanya menjadi gambaran semu dirinya si anak jadi kehilangan kenyataan tentang dirinya.

5) Anak yang selalu dimanjakan dengan segala kesenangan dan segala keinginanya selalu dipenuhi oleh orang tuanya, kalau sudah besar mungkin akan tumbuh menjadi manusia yang sombong, suka memaksakan kehendak.

b. Hidup Tanpa Kasih Sayang

Husain Mazhahiri dalam buku Sadulloh (2010, hlm.160), mengemukakan bahwa "kecintaan/kasih sayang meninggalkan bekasnya secara positif pada anak, dan menjadikan perilakunya dimasa yang akan datang memiliki sifat kasih sayang dan kecintaan. Sebaliknya, andaikan suatu kecintaan hilang dari rumah tangga, dan rumah tangga menjadi korban dan kebekuan dan kekerasan, maka masa depan anak akan terlempar pada marabahaya dan kepribadiamya, di masa datang akan memiliki sifat-sifat kekerasan dan emosional yang melampui batas.”Jadi anak yang hidup tanpa kasih sayang orang tuanya, pada masa yang akan datang setelah ia dewasa akan menampakkan kebencianya terhadap masyarakat sekitarnya, dan menunjukan ketidak pedulianya terhadap orang lain. Ia tidak menunjukan jiwa tolong 
menolong dan belas kasih sayang terhadap masyarakat sekitarnya, sehingga ia menjadi manusia yang tidak berperasaan.

Banyak peran yang semestinya dilakukan oleh seorang guru dalam menjalankan proses pendidikan diantaranya:

a. Guru Sebagai Pembimbing

Realitas di masyarakat menunjukan bahwa perilaku menyimpang dari anàk-anak seperti kebrutalan, kecanduan narkoba, pemurung, apatis dan sebagainya muncul karena dilatar belakangi oleh kondisi dimana anak tumbuh dalam keluarga yang tidak memberikan kepuasan kasih sayang terhadap dirinya. Hal ini menjadi tantangan pendidikan manakala kehidupan di kota besar dipenuhi oleh kesibukan orang tua dengan berbagai aktifitas pekerjaan.Dengan kasih sayang yang diberikan oleh guru, anak akan mendapatkan bimbingan untuk menjalani kehidupan ,baik yang di jalani saat ini maupun bekal di masa yang akan datang. Guru bagi anak sebagai tempat bertanya, mengadu meminta pendapat, berkeluh kesah, curhat berlindungan, dan posisi lainya dalam diri seorang anak didik.

b. Guru Pembentuk kepribadian

Pembentukan kepribadian anak disekolah merupakan hal yang tidak mudah, sulit kiranya dilakukan tanpa disertai dengan kasih sayang guru di sekolah bertanggung jawab membimbing anak didik, menjadi manusia bermoral, berhati nurani, kasih sayang terhadap sesama, dan sebagainya. Guru harus menunjukan sosok pribadi yang utuh, berpribadi stabil tidak emosionalan, penghayatan dan pelaksanaan moral dalam semua aspek kehidupan, sehingga akan menjadi teladan bagi anak didiknya. Di sekolah, guru yang baik akan memperhatikan hal ini sebagian dari perannya dalam menjalankan proses pendidikan. Pembentukan kepribadian anak di sekolah merupakan hal yang tidak mudah, pernah kita dikejutkan oleh pemberitaan media masa, seperti media 
cetak: koran, majalah, juga media elektronik: radio, televisi, ada anak yang bunuh diri karena ingin menyelamatkan harga diri dan rasa malu yang di alaminya karena tidak dapat membayar uang sekolah.

c. Guru Sebagai Tempat Perlindungan

Di sekolah anak akan minta perlindungan kepada gurunya, gurulah yang menjadi perlindungan bagi anak-anak tersebut. Pada kondisi ini, guru semestinya bijaksana, mendengarkan masalah yang dihadapi anak, memberikan nasihat dan sebisa mungkin menyadarkan tindakan yang dilakukan anak atau bahkan berupaya menjebati permasalahan anak dengan orang tuanya.

Ada anak yang kabur dari rumah akibat tidak menemukan kasih sayang dirumahnya. Dalam tindakan ini anak akan mencari perlindungan kepada siapa saja yang dianggap dekat atau yang dapat memberikan perhatian, beruntung jika mereka mendapat tempat berlindung pada orang yang berlatar belakang baik, misalnya kepada gurunya disekolah. Tetapi apabila anak bertemu dan bergaul dengan pemakan/pengedar narkoba misalnya maka anak akan berakibat merusak masa depannya.

Menyikapi kasus ini, selayaknya disekolah seorang guru dapat memberikan kasih sayang, maka anak akan merasa diperhatikan dan dilindungi. Pada kondisi ini, guru semestinya berlaku bijaksana, mendengarkan masalah yang dihadapi anak, memberikan nasihat dan mungkin menyadarkan tindakan yang dilakukan anak atau bahkan berupaya menjembatani permasalahan anak dengan orang tuanya.

d. Guru Sebagai Figur Teladan

Kasih sayang harus tergambarkan dalam perilaku ayah-ibu mereka, kasih sayang itu harus terlihat dalam pelukan, senyuman, bahkan dalam nada bicara orang tua mereka. Kasih sayang harus terwujud melalui perilaku secara kongkret atau tidak hanya bicara "saya 
menyayangi" atau "saya mencintai". Kasih sayang yang terwujud melalui perilaku, di samping secara psikologis akan dirasakan anak, juga perilaku itu akan menjadi contoh atau teladan apalagi anak yang menginjak remaja. Anak remaja memerlukan kasih sayang dengan kadar yang lebih besar dalam bentuk yang kongkret, ia masih hidup dalam lautan kebimbangan dan masamasa yang sangat kritis.

Seorang guru yang ramah, hangat dan selalu tersenyum, tidak memperlihatkan muka kusam atau kesal, merespon pembicaraan atau pertanyaan anak didik, akan menumbukan kondisi psikologis yang menyenangkan bagi anak. Anak tidak berbicara, dapat merencanakan isi hatinya saat menghadapi masalah dan anak akan senang melibatkan diri dalam kegiatan disekolah. Perilaku anak didik yang terbentuk ini pada dasarnya merupakan hasil dari mencontoh atau meneladani perilaku yang diperlihatkan pendidik dengan penuh kasih sayang.

e. Guru Sebagai Sumber Pengetahuan

Dalam proses pembelajaran dimana terjadi transformasi pengetahuan, sikap memberi dan melarang semestinya dilakukan dengan hati-hati terhadap anak didik. Pengetahuan dapat merubah sikap dan prilaku anak, perubahan dapat positif apabila pengetahuan yang diterima anak sesuai dengan hati-hati terhadap anak didik. Pengetahuan dapat merubah sikap dan perilaku anak sesuai dengan masanya dan sebaliknya apabila tidak sesuai akan membentuk perilaku anak yang negatif. Misalnya, pendidikan seks yang di berikan guru dengan tidak hati-hati akan berdampak pada perilaku anak yang salah tentang kehidupan seks. Oleh karena itu, seorang guru dalam menyampaikan pengetahuan harus didasari oleh kasih sayang. ${ }^{1}$

${ }^{1}$ Sadulloh, Uyoh, Pedagogik (Ilmu Mendidik). (Bandung, Alfabeta, 2011), h. 82-87 
Proses pembelajaran sudah seharusnya diwarnai dengan rasa kasih sayang dan kelembutan yang merupakan suasana menyejukkan dalam hubungan antara dosen dan mahasiswa. Prayitno (2005:17) mengemukakan bahwa dengan kasih sayang dan kelembutan kedekatan hubungan antara guru dan siswa akan terjaga dan produktif. Dosen dapat mewujudkan kasih sayang dan kelembutan melalui berbagai bentuk. Berkenaan dengan wujud kasih sayang dan kelembutan tersebut, Prayitno (2002:35) menyatakan bahwa kasih sayang dan kelembutan dapat terwujud melalui ketulusan, penghargaan, dan pemahaman secara empatik terhadap siswa sebagai pribadi. Memperkuat pendapat ini, Jalaluddin Rahmat (1985:53)

kasih sayang yang penuh dari kedua orang tua terutama, maka sudah barang tentu pada gilirannya akan sulit terjadi pertumbuhan dan perkembangan jiwa dan mental anak yang sehat dan normal, yang akhirnya sangat berpengaruh terhadap kepribadian anak itu sendiri.

\section{B. Kewibawaan}

Kewibawaan merupakan seperangkat hbungan antar personal yang mempertautkan peserta didik dengan pendidik dalam situasi pendidikan. Wibawa diartikan sebagai pancaran kelebihan atas orang lain dalam suasana pengakuan dan penerimaan yang nyaman dan tulus dari orang lain. (prayitno, 2009:50). Sadulloh (2010:164) menyebutkan guru sebagai pendidik harus memiliki kewibawaan, baikdalam pelajaran dikelas atau pun kegiatan diluar kelas, interaksi atau hubungan pendidikan tersebut, biasanya diwarnai dengan aspek pendidikan yang didasari kewibawaan. Hal ini menunjukan ada ikatan yang hakiki antara pendidikan dan kewibawaan. Kewibawaan adalah suatu pengaruh yang diakui 
kebenarannya, bukan sesuatu yang memaksa, kewibawaan harus berbanding dengan ketidakpercayaan peserta didik, jika pendidik kemampuannya tidak berbeda dengan peserta didik, maka kewibawaan itu sukar ditegakkan.

Burhanuddin (2002:182) menegaskan yang paling sulit di tumbuhkan pada seorang guru adalah masalah kewibawaannya. Kewibawaan adalah hal yang sangat penting dimiliki oleh seorang guru. Oleh karena itu, kewibawaan mempunyai kesungguhan, suatu kekuatan, sesuatu yang memberikan kesan, dan pengaruh. Pendidik harus memiliki kewibawaan dimata peserta didik. Karena peserta didik membutuhkan perlindungan, bantuan, bimbingan dan seterusnya dari pendidik. Membangun kewibawaan bukanlah hal yang mudah. Kewibawaan juga tidak muncul dalam waktu yang singkat. Butuh proses yang benar-benar matang ddalam diri sang pendidik sampai penampilan akan memengaruhi kewibawaan seseorang. Kompleksnya berbagai aspek sampai kepada kesimpulan kewibawaan, karena itu kewibawaan hanya ada pada orang dewasa. Kewibawaan pada pendidik mungkin saja akan menurun jika tidak ada stabilitas emosi pada pendidik. Selain itu setiap orang alam hal ini peserta didik memilikiharapan masing-masing terhadap kewibawaan pendidik yang mereka inginkan. Dalam mempertahankan kewibawaannya, (orang dewasa, orangtua, guru dan yang lainnya) perlu didukung oleh keadaan batin pemilik kewibawaan tersebut, yaitu:

1. Adanya rasa cinta; kewibawaan itu dapat dimiliki oleh seseorang, apabila hidup penuh kecintaan dengan atau kepada orang lain.

2. Adanya rasa demi kamu; demi kamu atau you attitude, adalah sikap yang dapat dilukiskan sebagai suatu tindakan, perintah atau anjuran, bukan untuk kepentingan orang yang memerintah, tetapi untuk kepentingan orang yang diperintah.

3. Adanya kelebihan batin; seorang guru yang menguasai bidang study yang tanggung jawabnya, bisa berlaku adil dan objektif, 
bijaksana, merupakan contoh-contoh yang dapat menimbulkan kewibawaan batin.

4. Adanya ketaatan kepada norma; menunjukkan dalam tingkah lakunya sebagai pendukung norma yang sungguh-sungguh, selalu menepati janji yang telah ibuat,disiplin dalam hal-hal yang telah gariskan (sadulloh, 2010:171-172).

Masalah kepribadian adalah suatu hal yang sangat enentukan tinggi rendahnya kewibawaan seorang guru dalam pandangan peserta didik dan masyarakat.setiap guru mmpunyai kepribadian masing-masing sesuai ciriciri pribadi yang satu dengan guru yang lainnya. Kepribadian merupakan sesuatu yang abstrak, hanya dapat dilihat lewat penampilan, tindakan, ucapan, cara berpakaian dan dalam menghadapisetiap persoalan. Yang dilakukannya dengan sadar merupakan suatu gambaran dari kepribadian orang tersebut. Pebuatan yang baik seing diartikan seseorang mempunyai kepribadian yang baik dan berakhlak mulia. Sebaliknya, jika seseorang melakukan perbuatan yang tidak baik, dalam pandangan masyarakat dikatakan orang tersebut tidak memiliki kepribadian yang baik dan akhlak yang tidak mulia(djamarah, 2010;39-40). Selanjutnya, dalam melaksanakan kewibawaan, pendidik hendaknya memperhatikan beberpa faktor: a). perkembangan anak secara pribadi. Anak yang seluruh potensi dan kemampuaannya berkembang secara optimal dan menjadi anak sebagai manusia mandiri, b). pendidik memberikan kesempatan kepada peserta didik untuk berinisiatif. c). kewibawaan didasarkan atas dasar kasih sayang pada anak. Pendidik berbuat sesuatu dengan kepentingan peserta didik, mengabdi kepada pesserta didik, bukan untuk kepentingan pendidik. $^{2}$

pendidikan melalui kewibawaan pendidik memasuki pribadi peserta didik dan peserta didik mengarahkan dirinya kepada pendidik dalam

\footnotetext{
${ }^{2}$ Rifma, Optimalisasi Pembinaan kompetensi pedagogik guru, (Jakarta, Kencana, 2016), h. $46-50$
} 
kondisi inilah dikembangkan pengakuan dan penerimaan, kasih sayang dan kelembutan, penguatan, tindakan tegas yang mendidik serta pengarahan dan keteladanan."4 Sejalan dengan pendapat di atas, M Dalyono (1996:27-28) mengemukakan proses pembelajaran merupakan kegiatan inti dalam proses pendidikan di mana dosen dan mahasiswa berinteraksi. Pendidikan pada hakikatnya adalah pelayanan bagi mahasiswa. Agar pelayanan tersebut mengubah tingkah laku mahasiswa ke arah perkembangan pribadi yang optimal, maka pelayanan itu hendaknya sesuai dengan sifat dan hakekat mahasiswa. Sedangkan Abu Ahmadi dan Widodo Supriyono (1991:158) menyatakan bahwa hubungan pendidik dan peserta didik dalam proses pembelajaran yang diharapkan adalah hubungan manusiawi yang di dalamnya tercakup unsur-unsur kasih sayang dan pengarahan serta keteladanan.

\section{Tanggung Jawab}

Tanggung jawab dalam kamus bahasa di artikan dengan keadaan wajib menanggung segala sesuatunya (kalau terjadi apa-apa boleh dituntut, dipersalahkan,diperkarakan dan segalanya); akan tetapi dalam tanggung jawab terhadap pendidikan setiap individu mempertanggung jawabkannya dihadapan Allah SWT. karna pada dirinya melekat kewajiban mnurut ilmu, mengamalkannya dan mengajarkannya. ${ }^{3}$

Pendidik adaah orang yang secara langsung bertanggung jawab untuk membawa peserta didik kearah yang dicita-citakan. Seorang pendidik memiliki tanggung jawab yang besar, untuk itu, diperlukan beberapa kompetensi pokok. Pertama, kompetensi keilmuan, seorang pendidik mesti memiliki ilmu yang kadarnya layak untuk mengajar pada tingkat dan program tertentu. Kedua, kompetensi keterampilan mengomunikasikan keilmuan, dan ketiga kompetensi moral akademik, saat sekarang telah

\footnotetext{
${ }^{3}$ Shabari Shaleh Anwar, Teologi pendidikan, (Jakarta, Indragiti TM,2010), h.181
} 
dirumuskan dalam empat kompetensi: pedagogik, kepribadian, profesional, dan komprtensi sosial. ${ }^{4}$

Guru sebagai pekerjaan profesi, kpadanya dibebankan tugas yang besar. Sebab profei membutuhkan keahlian yang telah terlatih secara matang. Kematangan seorang guru dalam mengemban profesiya tersebut terlihat dari pelaksanaan tugas dan tanggung jawabnya di lapangan atau pada saat berlangsungnya proses belajar-mengajar. Tugas dan tanggung jawab guru tersebut bukan hanya dalam hubungan dengan peserta didik di kelas akan tetapi menyangkut semua aspek yang bisa dilakukannya untuk menciptakan kondisi pembelajaran yang kondusif dan harmonis.

Guru sebagai tenaga edukatif yang yang bertugas pada suatu pendidikan tidak hanya harus mempunyai tanggung jawab ptofesional, dengan tanggung jawab profesional, tenaga edukatif tidak hanya sekedar mengajarkan mata pelajaran, akan tetapi juga bertanggung jawab dalam usaha pengembangan ilmu pengetahuan, dan membantu rekan kerjanya. ${ }^{5}$

\footnotetext{
${ }^{4}$ Haidar Putra Daulay, Pendidikan Islam Dalam Perspektif Filsafat, (Jakarta,Kencana, 2014) h. 21

${ }^{5}$ Samsul Nizar, dan Zainal Efendi Hasibuan; Pendidik Ideal, (Depok, Prenada Media, 2018), h.151
} 


\section{BAB III}

\section{PENUTUP}

\section{A. Kesimpulan}

Kasih Sayang, Kewibawaan, dan Tanggung Jawab Pendidikan, merupakan ruh dari pendidikan, tidak dapat di pisahkan satu sama lainya . ketiga hal tersebut dapat dikatakan merupakan prasyarat dalam melaksanakan pendidikan. Pada praktiknya, ternyata menerapkan kasih sayang, kewibawaan, dan tanggung jawab dalam proses pendidikan tidak mudah, banyak hambatan dan kendala yang dihadapi pendidik, baik berkaitan dengan pemahaman maupun kemampuan pendidik.

\section{B. Saran}

Penulis menyadari bahwa dalam pembuatan makalah ini belumlah terlalu sempurna dan masih banyak kekurangan. Dan penulis akan memperbaiki serta mengumpulkan setiap masukan-masukan yang mendukung kesempurnaan makalahini. 


\section{DAFTAR PUSTAKA}

Baharits, A. H. S. (1996). Tanggung jawab ayah terhadap anak laki-laki. Gema Insani.

Haidar Putra Daulay, Pendidikan Islam Dalam Perspektif Filsafat, Jakarta,Kencana, 2014

Jamaluddin, J., Komarudin, A., \& Rahman, A. A. (2019). Bimbingan orang tua dalam mengembangkan kepribadian anak. Atthulab: Islamic Religion Teaching and Learning Journal, 4(2), 170-184.

Rifma, Optimalisasi Pembinaan kompetensi pedagogik guru,Jakarta, Kencana, 2016

Sadulloh, Uyoh. Pedagogik (Ilmu Mendidik). Bandung: Alfabeta, 2011

Samsul Nizar, dan Zainal Efendi Hasibuan; Pendidik Ideal, Depok, Prenada Media, 2018

Shabari Shaleh Anwar, Teologi pendidikan, Jakarta, Indragiti TM,2010 